\title{
GAMBARAN PENGETAHUAN IBU TENTANG KESEHATAN FISIK SELAMA MENOPAUSE DI KLINIK PRATAMA HENY KASIH KOTA MEDAN TAHUN 2021
}

\author{
Rina Luginar Tambunan', Desriati Sinaga ${ }^{2 *}$ \\ Program Studi D3 Kebidanan STIKes Santa Elisabeth, Medan, Indonesia \\ Email: luginarrina98@gmail.com ${ }^{\mathbf{1}}$, sinagadesri9@gmail.com ${ }^{2 *}$
}

\begin{abstract}
Abstrak
Menopause merupakan peristiwa alami dari siklus kehidupan dengan perubahan-perubahan fisik mulai dari rambut, mata, kulit sampai ke organ-organ fisik lainnya. Kesehatan fisik Ibu menopause digambarkan pada keadaan organ tubuh yang dapat berfungsi secara normal dan kondisi badan baik yang sangat memungkinkan hidup secara produktif di masa menopause dalam menjalankan aktivitas sehari-hari. Rancangan penelitian ini bertujuan untuk mengetahui gambaran pengetahuan ibu menopause tentang kesehatan fisik selama menopause di Klinik Pratama Heny Kasih Kota Medan Tahun 2021 Penelitian menggunakan metode deskriptif. Sampel dalam penelitian ini adalah Ibu yang telah memasuki fase menopause sebanyak 20 responden dari 72 Ibu yang berkunjung memliki usia dia atas 40 sampai 80 tahun. Instrument penelitian menggunakan kuesioner data primer dan analisis data Univariat menggunakan SPSS dan disajikan dengan menggunakan tabel terbuka. Hasil penelitian dengan Pengetahuan responden dalam penelitian ini mayoritas baik sebanyak 11 responden (55\%), cukup sebanyak 9 responden (45\%), dan kurang tidak ditemukan. Responden yang berpengetahuan baik berdasarkan tingkat pendidikan terbanyak dari SMA yaitu sebanyak (30\%), berdasarkan Pekerjaan terbanyak dari Ibu rumah tangga yaitu sebanyak (25\%), dan Sumber informasi terbanyak dari tenaga kesehatan yaitu sebanyak (30\%). Kesimpulan dari penelitian ini yaitu pengetahuan ibu menopause tentang kesehatan fisik selama menopause mayoritas berpengetahuan baik. Ibu menopause diharapkan dapat melakukan berbagai pola hidup sehat, serta rutin memeriksakan kesehatan diri untuk tetap menjaga kesehatan fisik selama menopause.
\end{abstract}

Kata kunci: Ibu, Kesehatan fisik, Menopause, Pengetahuan

\begin{abstract}
Menopause is a natural event of the life cycle with physical changes ranging from hair, eyes, skin to other physical organs. The physical health of postmenopausal women is described in terms of the state of the body's organs that can function normally and in good body condition which makes it possible to live productively during menopause in carrying out daily activities. The design of this study aims to describe the knowledge of menopausal women about physical health during menopause at the Pratama Heny Kasih Clinic, Medan City in 2021. The study used a descriptive method. The sample in this study were mothers who had entered the menopause phase as many as 20 respondents from 72 mothers who visited had their ages over 40 to 80 years. The research instrument used a primary data questionnaire and Univariate data analysis using SPSS and presented using an open table. The results of the study with the knowledge of the respondents in this study the majority were good, as many as 11 respondents (55\%), 9 respondents (45\%), and less were not found. Respondents who have good knowledge based on education level are mostly from SMA (30\%), based on occupation, most are housewives (25\%), and the most sources of information are health workers (30\%). The conclusion of this study is that the majority of
\end{abstract}


menopausal mothers have good knowledge about physical health during menopause. Menopausal mothers are expected to be able to carry out various healthy lifestyles, as well as routinely check their health to maintain physical health during menopause.

Keywords: Mothers, Physical Health, Menopausal, Knowledge

\section{Pendahuluan}

Data demografi WHO menunjukan bahwa setiap tahun, 25 juta wanita dari seluruh dunia mengalami menopause dan akan menghasilkan 1,2 miliar wanita pascamenopause pada tahun 2030 jumlah perempuan di seluruh dunia. Data Department of Reproductive Health WHO memperkirakan di negara Asia menjadi salah satu dengan jumlah menopause terbanyak pada tahun 2025 melonjak dari 107 juta jiwa menjadi 373 juta jiwa (Shim et al., 2018). Menopause memang bukan penyakit melainkan gejala alami yang akan dialami usia 40-an atau 50-an wanita menopause dengan gejala fisik semburan panas (hot flashes), banjir keringat maupun semburan panas saat tidur dimalam hari, vagina mengering, jantung berdebar, kelelahan berlebihan, gangguan kulit (WHO, 1981) (Hekhmawati, 2016). Masalah-masalah yang timbul dari perubahan fisik tersebut akan mendatangkan gejala maupun perubahan kesehatan fisik yang dialami ibu selama menopause berlangsung (Linda \& Yetti R., 2019).

Setelah menopause, ovarium membuat kadar hormone estrogen dan progesterone menjadi sangat rendah. Kadar hormone yang rendah secara permanen, berakibat hilangnya aktivitas folikuler ovarium dan membuat seorang wanita tidak akan bisa lagi hamil, bahkan dapat meningkatkan risiko kesehatan tertentu (Arini, 2018). Transisi dari setiap tahapan menopause sendiri umumnya berlangsung antara satu hingga empat tahun yaitu sebagai: Pramenopause, Perimenopause, Menopause dan Pascamenopause (Asriati et al., 2019). Menopause harusnya bisa menjadi awal dari sebuah periode kehidupan positif dan memuaskan. Termasuk didalamnya adalah mengendalikan berat badan, menjaga kesehatan mental, dan berhati-hati terhadap penyakit-penyakit berat seperti kanker (khusunya pada organ reproduksi), penyakit jantung, dan perawatan gangguan sistem urine (Matjino, 2019).

Meningkatnya usia harapan hidup wanita di Indonesia, pada tahun 2025 diperkirakan akan ada 60 juta perempuan menopause. Pada Tahun 2017 di Indonesia tercatat sebesar 23,4 juta usia lanjut $8,97 \%$ dan 7,4 \% dari total penduduk adalah usia menopause(Indonesia, 2017). Sementara perkiraan umur rata-rata usia menopause di Indonesia adalah 50 tahun. Di Sumatra Utara menurut Data Informasi Profil Kesehatan Indonesia 2017, dari jumlah penduduk perempuan wanita subur usia 15-49 tahun 3.700.478 jiwa dari total 7.145.251 wanita di Sumatra utara, dengan jenis kelamin perempuan usia 40-49 tahun sebesar 17.894.421 keseluruhan perempuan di Indonesia (Kesehatan, 2018).

Negara Indonesia sebagai salah satu penyumbang wanita usia produktif - wanita usia subur serbesar 162.257.848 yang memasuki masa menopause dan kemungkinan akan terus meningkat seluruh jumlah penduduk wanita berdasarkan data olah dari Sensus Penduduk 2010. Sejalan dengan Indikator sasaran Program Pembagunan Kesehatan di Indonesia Tahun 2019, kualitas hidup Penduduk wanita usia produktif 15-64 tahun 
sebanyak 90. 246.841 dari 133.416.946 penduduk wanita di Indonesia dengan kepadatan penduduk Sumatra utara 14.562.549 (21,75\%) jiwa (Prabhakara, 2019).

Variasi yang cukup besar dalam pelaporan Eastern Mediterranen Health Journal ditemukan gejala menopause oleh wanita di seluruh dunia dengan Amerika Latin, yang paling banyak dilaporkan gejala berupa hot flushes $(68,9 \%)$ diikuti oleh gangguan tidur $(68,4 \%)$. Di Australia, menopause sebagian besar dikaitkan dengan flushes dan diikuti oleh keringat malam. Di Nigeria, ketidaknyamanan sendi dan otot adalah yang paling banyak gejala yang sering dilaporkan (59\%). Di Mesir, satu studi menemukan gejala yang paling umum kelelahan diikuti oleh sakit kepala. Studi Mesir melaporkan yang paling umum gejala pascamenopause adalah nyeri sendi $(90,3 \%)$, masalah tidur $(84,0 \%)$ dan fisik dan kelelahan mental (80,0\%). Wanita dari negara-negara di Asia Timur dan Tenggara dilaporkan nyeri sendi dan otot sebagai keluhan yang paling sering terjadi $(8,9 \%)$ (Kamal \& Seedhom, 2017).

Berdasarkan data Survey Demografi Kesehatan Indonesia (SDKI) tahun 2017 menunjukan bahwa proporsi wanita 30-34 tahun di Indonesia yang mengalami menopause sebanyak 9,7\%, umur 35-39 tahun sebanyak 11,0\%, umur 40-41 tahun sebanyak $12,7 \%$, umur $42-43$ tahun sebanyak $14,2 \%$, umur $44-45$ tahun sebanyak $17,1 \%$, umur 46-47 tahun sebanyak $26,7 \%$, umur $48-49$ tahun sebanyak $43,1 \%$ atau jumlah total sekitar $16,1 \%$ meningkat sekitar $2 \%$. Sebagai data pembanding dari jumlah penduduk Indonesia hasil SP2020 menunjukan pada usia 40-55 tahun sebanyak 21, 88\% dengan penduduk usia produktif (15-64) Tahun sebesar 70,72\% dari 270,20 juta jiwa (Badan Pusat Statistik, 2021)

Olahraga yang baik dan benar juga mampu menstimulus aliran oksigen ke seluruh tubuh, mengisi kembali oksigen kedalam jaringan otot, sedangkan olahraga yang tidak benar akan berakibat sebaliknya. Ketika merasa sangat stress akibat gejala-gejala menopause yang sedang dialami, olahraga dapat membantu meredakannya dengan menyeimbangkan hormon-hormon pada tubuh. Berdasarkan data hasil survey penelitian "Gambaran Pengetahuan Ibu tentang Persiapan Fisik dan Psikis Memasuki Masa Menopause" dengan kesimpulan hasil ibu yang berpengetahuan tentang persiapan fisik memasuki masa menopause yaitu kategori berpengetahuan baik sebanyak 22,5\% responden, pengetahuan cukup sebanyak $67,5 \%$ responden, dan pengetahuan yang kurang sebanyak 10\% responden (Asriati et al., 2019). Pengetahuan yang baik akan mempengaruhi sikap ibu terhadap perilaku hidup sehat dalam mengatasi masalah mengenai ketidak mengertian dalam menghadapi menopause (Cipto et al., 2020).

Berdasarkan hasil data survey yang peneliti lakukan di klinik Pratama Heny Kasih pada bulan Januari 2021. Dengan acuan buku kunjungan berobat pasien selama satu bulan terakhir, Ibu yang berkunjung memliki usia dia atas 45 sampai 55 tahun. Ibu mengatakan mengalami gejala dan tanda menopause akan tetapi masih kurang memahami pengertian dan dampak dari menopause pada kehidupan Ibu. Gejala yang dialami Ibu sering menjadi hambatan dan keluhan kesehatan fisik dalam melakukan aktifitas fisik sehari-hari. Berdasarkan uraian diatas, maka peneliti merasa perlu untuk melakukan penelitian yang berkaitan dengan kesehatan fisik dalam gejala yang tampak pada ibu menopause mengenai : "Gambaran Pengetahuan Ibu Tentang Kesehatan Fisik Selama Menopause di Klinik Pratama Heny Kasih Kota Medan Tahun 2021”. 


\section{Metode Penelitian}

Penelitian ini disajikan secara deskriptif dengan menggunakan tabel distribusi frekuensi dan presentase masing-masing karakteristik, untuk mengetahui gambaran pengetahuan ibu tentang kesehatan fisik selama menopause di klinik Pratama Henny Kasih Tahun 2021. Sampel penelitian adalah Ibu yang telah memasuki fase menopause sebanyak 20 responden secara purposive sampling, dengan penelitian data primer dan data sekunder. Diberikan sebanyak 18 pertanyaan yang diajukan kepada Ibu menopause sebagai responden berdasarkan anamnesis dan data kunjungan pasien di Klinik Pratama Heny Kasih, bulan Maret s/d April tahun 2021. Sedangkan instrument penelitian menggunakan format check-list kuesioner pada sesi wawancara dan analisis data Univariat, yang kemudian diolah dalam bentuk program data melalui uji validitas dan realiabilitas menggunakan SPSS (Miftachul ulum, 2016). Penelitian ini sudah mendapatkan surat keterangan layak etik dan peneliti sudah lulus dari komisi etik penelitian kesehatan STIKes Santa Elisabeth Medan dengan No. : 0077/KEPK-SE/PEDT/III/2021. surat izin meneliti dengan Nomor : 322/STIKes/Klinik-Penelitian/III/2021.

\section{Hasil dan Pembahasan}

Berdasarkan hasil penelitian yang diperoleh terhadap karakteristik ibu menopause tentang kesehatan fisik selama menopause di Klinik Pratama Heny Kasih Kota Medan yang dilaksanakan pada bulan Maret s/d April 2021 disajikan pada tabel berikut :

Tabel 1. Distribusi Frekuensi Pengetahuan Ibu Tentang Kesehatan Fisik Selama Menopause di Klinik Pratama Heny Kasih Kota Medan Tahun 2021

\begin{tabular}{llll}
\hline No. & Pengetahuan & f & \% \\
\hline 1 & Baik & 11 & 55 \\
2 & Cukup & 9 & 45 \\
3 & Kurang & 0 & 0 \\
\hline
\end{tabular}

Tabel 1, Menunjukkan bahwa Ibu dengan kesehatan fisik selama menopause di klinik pratama henny kasih berada pada pengetahuan baik dan cukup. Sebagian besar ibu menopause memiliki pengetahuan yang baik yaitu sebanyak 11 orang (55\%), dibandingkan ibu yang berpengetahuan cukup sebanyak 9 orang (45\%). 
Tabel 2. Distribusi Frekuensi Karakteristik Ibu berdasarkan pendidikan, pekerjaan, dan sumber informasi tentang kesehatan fisik selama menopause di Klinik Pratama Heny Kasih Kota Medan Tahun 2021

\begin{tabular}{|c|c|c|c|}
\hline No & Karakteristik & $\mathbf{f}$ & $\%$ \\
\hline 1 & $\begin{array}{l}\text { Pendidikan } \\
\text { Tidak Sekolah } \\
\text { SD } \\
\text { SMP } \\
\text { SMA } \\
\text { Perguruan Tinggi }\end{array}$ & $\begin{array}{l}0 \\
3 \\
3 \\
10 \\
4\end{array}$ & $\begin{array}{l}0 \\
15 \\
15 \\
50 \\
20\end{array}$ \\
\hline 2 & $\begin{array}{l}\text { Pekerjaan } \\
\text { IRT } \\
\text { Petani } \\
\text { Wiraswasta } \\
\text { Karyawan Swasta } \\
\text { PNS / BUMN }\end{array}$ & $\begin{array}{l}10 \\
4 \\
4 \\
0 \\
2\end{array}$ & $\begin{array}{l}50 \\
20 \\
20 \\
0 \\
10\end{array}$ \\
\hline 3 & $\begin{array}{l}\text { SumberInformasi } \\
\text { Tenaga Kesehatan } \\
\text { Keluarga } \\
\text { Lingkungan Sekitar } \\
\text { Teman } \\
\text { Media cetak } \\
\text { Internet }\end{array}$ & $\begin{array}{l}10 \\
2 \\
2 \\
2 \\
0 \\
4\end{array}$ & $\begin{array}{l}50 \\
10 \\
10 \\
10 \\
0 \\
20\end{array}$ \\
\hline
\end{tabular}

Tabel 2, Menunjukkan bahwa berdasarkan tabel kolom no.1 sebagian besar pendidikan ibu menopause adalah SMA sebanyak 10 orang (50\%), SMP sebanyak 3 orang (15\%), SD sebanyak 3 orang (15\%), Sarjana sebanyak 4 orang (20\%), dan yang tidak sekolah sebanyak 0 orang $(0 \%)$. Pada kolom no.2, sebagian besar ibu menopause bekerja sebagai IRT sebanyak 10 orang (50\%), Petani 4 orang (20\%), Wiraswasta 4 orang (20\%), dan PNS 2 orang $(10 \%)$ dan karyawan swasta sebanyak 0 orang $(0 \%)$. Pada kolom no. 3, sebagian besar sumber informasi ibu didapatkan dari Tenaga kesehatan sebanyak 10 orang $(50 \%)$, dari keluarga sebanyak 2 orang (10\%), dari lingkungan sekitar 2 orang $(10 \%)$, teman 2 orang (10\%), Media cetak $0(0 \%)$, dan internet sebanyak 4 orang (20\%).

Tabel 3.Distribusi Frekuensi Gambaran Pengetahuan Ibu Tentang Kesehatan Fisik Selama Menopause Berdasarkan Pendidikan di Klinik Pratama Heny KasihTahun 2021

\begin{tabular}{|c|c|c|c|c|c|c|c|c|c|}
\hline \multirow{3}{*}{ No } & \multirow{3}{*}{ Pendidikan } & \multicolumn{6}{|c|}{ Pengetahuan } & \multirow{2}{*}{\multicolumn{2}{|c|}{ Total }} \\
\hline & & \multicolumn{2}{|l|}{ Baik } & \multicolumn{2}{|l|}{ Cukup } & \multicolumn{2}{|c|}{ Kurang } & & \\
\hline & & f & $\%$ & f & $\%$ & $\mathbf{f}$ & $\%$ & f & $\%$ \\
\hline 1 & TidakSekolah & 0 & 0 & 0 & 0 & 0 & 0 & 0 & 0 \\
\hline 2 & SD & 1 & 5 & 2 & 10 & 0 & 0 & 3 & 15 \\
\hline 3 & SMP & 1 & 5 & 2 & 10 & 0 & 0 & 3 & 15 \\
\hline 4 & SMA & 6 & 30 & 4 & 20 & 0 & 0 & 10 & 50 \\
\hline 5 & Perguruan Tinggi & 3 & 15 & 1 & 5 & 0 & 0 & 4 & 20 \\
\hline
\end{tabular}


Dari tabel 3, dapat dilihat bahwa pengetahuan ibu menopause tentang kesehatan fisik berdasarkan Pendidikan yang berpengetahuan baik pada responden sebanyak 11 orang $(55 \%)$, dari tingkat pendidikan SMA 6 orang (30\%), Perguruan tinggi 3 orang (15\%), sedangkan berpengetahuan cukup sebanyak 9 orang $(45 \%)$ dari tingkat pendidikan SD 2 orang (10\%), Perguruan tinggi 1 orang (5\%).

\section{Tabel 4 Distribusi Frekuensi Gambaran Pengetahuan Ibu Tentang Kesehatan Fisik Selama Menopause Berdasarkan Pekerjaan di Klinik Pratama Heny Kasih Tahun 2021}

\begin{tabular}{|c|c|c|c|c|c|c|c|c|c|}
\hline \multirow{3}{*}{ No } & \multirow{3}{*}{ Pekerjaan } & \multicolumn{6}{|c|}{ Pengetahuan } & \multirow{2}{*}{\multicolumn{2}{|c|}{ Total }} \\
\hline & & \multicolumn{2}{|c|}{ Baik } & \multicolumn{2}{|c|}{ Cukup } & \multicolumn{2}{|c|}{ Kurang } & & \\
\hline & & f & $\%$ & $\mathbf{f}$ & $\%$ & $\mathbf{f}$ & $\%$ & $\mathbf{f}$ & $\%$ \\
\hline 1 & IRT & 5 & 25 & 5 & 25 & 0 & 0 & 10 & 50 \\
\hline 2 & Petani & 1 & 5 & 3 & 15 & 0 & 0 & 4 & 20 \\
\hline 3 & Wiraswasta & 3 & 15 & 1 & 5 & 0 & 0 & 4 & 20 \\
\hline 4 & Karyawan & 0 & 0 & 0 & 0 & 0 & 0 & 0 & 0 \\
\hline 5 & PNS / BUMN & 2 & 10 & 0 & 0 & 0 & 0 & 2 & 10 \\
\hline
\end{tabular}

Dari tabel 4, dapat dilihat bahwa pengetahuan ibu menopause tentang kesehatan fisik berdasarkan Pekerjaan, yang berpengetahuan baik sebanyak 11 orang (55\%), dengan pekerjaan IRT 5 orang (25\%). Sedangkan Ibu yang berpengetahuan cukup sebanyak 9 orang $(45 \%)$, dengan pekerjaan sebagai IRT sebanyak 5 orang (25\%), dan tidak di temukan Ibu dengan pekerjaan Karyawan Swasta pada penelitian.

Tabel 5 Distribusi Frekuensi Gambaran Pengetahuan Ibu Tentang Kesehatan Fisik Selama Menopause Berdasarkan Sumber Informasi di Klinik Pratama Heny KasihTahun 2021

\begin{tabular}{|c|c|c|c|c|c|c|c|c|c|}
\hline \multirow{3}{*}{ No } & \multirow{3}{*}{ SumberInformasi } & \multicolumn{6}{|c|}{ Pengetahuan } & \multirow{2}{*}{\multicolumn{2}{|c|}{ Total }} \\
\hline & & \multicolumn{2}{|c|}{ Baik } & \multicolumn{2}{|c|}{ Cukup } & \multicolumn{2}{|c|}{ Kurang } & & \\
\hline & & $\mathbf{f}$ & $\%$ & f & $\%$ & $\mathbf{f}$ & $\%$ & f & $\%$ \\
\hline 1 & Tenaga Kesehatan & 6 & 30 & 4 & 20 & 0 & 0 & 10 & 50 \\
\hline 2 & Keluarga & 1 & 5 & 1 & 5 & 0 & 0 & 2 & 10 \\
\hline 3 & Lingkungan Sekitar & 2 & 10 & 0 & 0 & 0 & 0 & 2 & 10 \\
\hline 4 & Teman & 0 & 0 & 2 & 10 & 0 & 0 & 2 & 10 \\
\hline 5 & Media cetak & 0 & 0 & 0 & 0 & 0 & 0 & 0 & 0 \\
\hline 6 & Internet & 2 & 10 & 2 & 10 & 0 & 0 & 4 & 20 \\
\hline
\end{tabular}

Dari Tabel 5, dapat dilihat bahwa pengetahuan ibu menopause tentang kesehatan fisik selama menopause berdasarkan sumber informasi dengan ibu yang berpengetahuan baik sebanyak 11 orang (55\%), dengan sumber informai dari Tenaga kesehatan 6 orang (30\%). Sedangkan Ibu yang berpengetahuan cukup sebanyak 9 orang (45\%), dengan sumber informasi Tenaga kesehatan sebanyak 4 orang (20\%), dan tidak di temukan sumber informasi media cetak dan pengetahuan kurang pada penelitian. 


\section{Pembahasan}

Berdasarkan penelitian yang dilakukan oleh peneliti mengenai Gambaran Pengetahuan Ibu tentang Kesehatan Fisik Selama Menopause di Klinik Pratama Henny Kasih tahun 2021 telah diperoleh hasil penelitian yang dapat dijelaskan sebagai berikut.

\section{Gambaran Pengetahuan Ibu Tentang Kesehatan Fisik Selama Menopause}

Berdasarkan hasil penelitian tabel 1, diketahui gambaran pengetahuan ibu menopause tentang kesehatan fisik sebagian besar responden berpengetahuan baik sebanyak 11 orang (55\%), Ibu berpengetahuan cukup sebanyak 9 orang (45\%), dan berpengetahuan kurang tidak ditemukan pada jawaban responden. Hal ini menjadi dasar setiap Ibu dalam mengetahui perubahan diri yang dialami selama menopause, tanpa dampak berlebih pada keluhan dan gangguan kesehatan dalam beraktivitas mengenai kesehatan fisik ibu selama menopause.

Hasil penelitian ini tidak sejalan dengan penelitian (Rakkuea et al., 2016), bahwa distribusi frekuensi pengetahuan tentang menopause menunjukkan distribusi yang tertinggi adalah tingkat pengetahuan kurang yang dikumpulkan menggunakan kuesioner didapatkan sebanyak 21 responden $(61,8 \%)$, kemudian cukup sebanyak 10 responden $(29,4 \%)$, dan baik sebanyak 3 responden $(8,8 \%)$. Menopause umumnya dianggap sebagai hal yang wajar oleh wanita, khususnya wanita-wanita di pedesaan. Hal ini sebagaimana disimpulkan dalam beberapa penelitian terdahulu antara lain penelitian Entisar \& Amaal (2015) yang menunjukkan bahwa sebagian besar ibu memiliki pengetahuan yang kurang tentang tanda dan gejala menopause $(72 \%)$, memiliki pengetahuan kurang tentang faktorfaktor yang berhubungan dengan menopause (66\%), dan pengetahuan tentang pemeliharaan kesehatan dan manajemen menopause (47\%).

Sejalan dengan penelitian (Theresia Bong et al., 2019), didapati bahwa pengetahuan atau cognitive merupakan dominan yang sangat penting dalam bentuk tindakan seseorang. Ibu menopause dikatakan memiliki pengetahuan apabila tahu atau mampu mengingat materi yang diperoleh, tentang objek tersebut, memahami atau mampu untuk menjelaskan kembali materi yang diperoleh secara benar, mampu mengaplikasikan menggunakan prinsip materi yang diperoleh dan mampu memberikan penilaian terhadap prinsip atau materi yang sudah diterapkan atau praktekan.

Menurut asumsi peneliti, bahwa pengetahuan responden mayoritas berpengetahuan baik, berdasarkan data tersebut secara umum dapat ditarik kesimpulan bahwa terjadi peningkatan pengetahuan ibu Menopause tentang kesehatan fisik dengan cara mengenali dan mengatasi tanda gejala agar tetap hidup sehat selama masa menopause. Pengetahuan ibu menopause juga dikaitkan dengan tingkat pendidikan, dibuktikan antara sebelum diberikan edukasi kesehatan dan sesudah diberikan edukasi kesehatan melalui media leaflet.

\section{Gambaran Karakteristik Pendidikan, Pekerjaan, dan Sumber Informasi Ibu Menopause}

Berdasarkan hasil penelitian yang dilakukan bulan Maret-April 2021 pada tabel 2, diketahui dari 20 responden bahwa ibu berpengetahuan baik, dengan karakteristik pendidikan, pekerjaan, dan sumber informasi. Pada tingkat pendidikan sebagian besar adalah SMA, Pekerjaan sebagian besar adalah Ibu Rumah Tangga, dan sumber informasi sebagian besar adalah tenaga kesehatan. Dengan mengkaji lebih detail pada setiap ciri, sesuai dengan gambaran tujuan setiap poin yang disampaikan. Didapati setiap Ibu menopause tampak dengan individu karakter yang beragam dan mendukung pengetahuan Ibu menopause tentang kesehatan fisik selama menopause. 
Berdasarkan hasil penelitian yang telah dilakukan (Indrawati et al., 2019), Karakteristik usia menopause sebgaian besar berusia antara 45-50 tahun, berdasarkan status pekerjaan informasi kunci sebagian besar adalah swasta, terkait perubahan fisik wanita menopause dan pola aktifitas seksualitas. Selain itu ibu menopause juga kembali di berikan dengan edukasi tentang menopause dan perubahan fisik yang akan dan telah dialami setiap wanita. Sesuai dengan hasil penelitian Dewi (2010), didapatkan sebagian wanita ada yang belum mengerti dan tidak mengetahui secara jelas kalau mereka berada pada masa menopause dan sebagian premenopause untuk membedakan perubahan fisik dan psikologis pada kesehatan tubuh selama menopause.

Menurut asumsi peneliti, bahwa karakteristik ibu menopause berpengetahuan baik menunjukan gambaran ciri khas tanda gejala menopause yang mempengaruhi kesehatan fisik selama menopause. Hal ini menunjukan bahwa setiap ibu menopause memiliki kriteria yang berbeda akan tetapi sejalan dengan gambaran poin perencanaan penelitian. Pada setiap responden menunjukan bahwa karakteristik menjadi salah satu sumber dalam mengali pengetahuan ibu untuk mengetahui hasil evaluasi peneliti tentang kesehatan fisik selama menopause.

\section{Gambaran Pengetahuan Ibu Menopause Tentang Kesehatan Fisik Selama Menopause Berdasarkan Pendidikan}

Berdasarkan tabel 3, hasil penelitian diperoleh bahwa pengetahuan ibu menopause tentang kesehatan fisik selama menopause berpengetahuan baik, berdasarkan tingkat pendidikan SMA dan Perguruan Tinggi, dibandingkan berpengetahuan cukup, sedangkan ibu berpengetahuan kurang tidak di temukan berdasarkan pendidikan ibu.

Hasil penelitian ini tidak sejalan dengan penelitian yang dilakukan (Manalu, 2020), berjudul Gambaran Pengetahuan Ibu Menopause Tentang Perubahan Fisik Selama Masa Menopause Di Desa Hutaraja Simanungkalit Kecamatan Sipoholon Kabupaten Tapanuli Utara, dari hasil penelitian dapat diketahui bahwa ibu menopause lebih banyak memiliki pengetahuan cukup di bandingkan dengan ibu menopause pengetahuan baik. Berdasarkan pendidikan ditemukan lebih besar berpengetahuan kurang pada tingkat pendidikan SD sebanyak 13 responden (26\%) dan lebih kecil berpengetahuan baik pada tingkat pendidikan SMA sebanyak 1 responden (2\%). Hal ini sejalan dengan teori bahwa semakin tinggi pengetahuan seseorang maka semakin baik pengetahuannya, dan dapat disimpulkan bahwa pendidikan akan mempengaruhi pengetahuan ibu menopause tentang perubahan fisik selama masa menopause

Sejalan dengan penelitian (Saraniga, 2017), yang menyatakan Pengetahuan Tentang Menopause Pada Wanita Usia 40-60 Tahun Di Kelurahan Anduonohu Kecamatan Posia Kota Kendari Tahun 2017 bahwa hasil penelitian menyatakan sebagian besar responden memiliki pengetahuan yang baik tentang menopause. Dilihat bahwa responden yang memiliki pengetahuan tentang menopause dalam kategori baik sebagian besar berpendidikan tinggi sebanyak 18 orang $(51,4 \%)$, sedangkan responden yang memiliki pengetahuan tentang menopause dalam kategori cukup dan kurang sebagian besar berpendidikan dasar dan menengah, namun perlu ditekankan bahwa seorang yang berpendidikan rendah tidak berarti mutlak berpengetahuan rendah pula.

Menurut asumsi peneliti, bahwa tingkat pendidikan ibu menopause berpengetahuan baik, pada tingkat pendidikan SMA dan Perguruan Tinggi. Hal ini menunjukkan bahwa ibu menopause memiliki pengetahuan yang baik tentang kesehatan fisik selama masa menopause. Dengan melihat keseluruhan Ibu yang memiliki pengetahaun baik dan cukup, pada tingkat pendidikan tinggi atau rendah ibu menopause, maka setiap ibu memiliki peluang yang sama dalam menerima pengetahuan tentang kesehatan fisik selama menopause. Hal ini juga dipengaruhi oleh faktor sumber infomasi, 
interpersonal, keluarga maupun pekerjaan. Sejalan dengan teori pengetahuan terkait dengan pendidikan dalam mengembangkan kemampuan di dalam dan diluar sekolah, saat menopause yang dirasakan pada kesehatan fisik dapat dikenali dan diatasi.

\section{Gambaran Pengetahuan Ibu Menopause Tentang Kesehatan Fisik Menopause Berdasarkan Pekerjaan}

Selama

Berdasarkan hasil penelitian tabel 4 diperoleh bahwa pengetahuan ibu menopause tentang kesehatan fisik selama menopause berdasarkan pekerjaan mayoritas yang berpengetahuan baik sebanyak 11 orang (55\%), dari dominasi pekerjaan Ibu Rumah Tangga, Wiraswasta dan PNS. Dibandingkan berpengetahuan cukup sebanyak 9 orang (45\%), dari pekerjaan Ibu Rumah Tangga dan Petani.

Hasil penelitian ini tidak sejalan dengan penelitian (Asifah et al., 2021), bahwa diperoleh simpulan pengetahuan wanita dalam menghadapi menopause di Pedukuhan Gowok Kabupaten Sleman yaitu berada dalam ketegori kurang. Distribusi karakteristik responden berdasarkan pekerjaan menunjukkan dari 60 responden (100\%), sebanyak 39 responden $(65 \%)$ adalah ibu rumah tangga (IRT), dan 14 responden $(23,3 \%)$ adalah karyawan. Adapun tingkat pengetahuan wanita dalam menghadapi menopause berdasarkan pekerjaan menunjukkan bahwa sebanyak 25 responden $(41,7 \%)$ yang memiliki tingkat pengetahuan kurang adalah IRT.

Sejalan dengan hasil penelitian (Tsuraya, 2018), berdasarkan hasil penelitian yang dilakukan peneliti didapatkan bahwa mayoritas responden merupakan Ibu Rumah Tangga (IRT) sebanyak 49 orang $(53,3 \%)$. Pekerjaan wanita menopause juga dapat dikaitkan dengan kualitas hidup wanita menopause itu sendiri. Hal ini sejalan dengan penelitian yang dilakukan Ratna, Tendean, dan Suparman (2013) yang menyatakan bahwa mayoritas responden wanita menopause merupakan Ibu Rumah Tangga (IRT) sebanyak 47 orang $(70,1 \%)$.

Menurut asumsi peneliti, Ibu menopause berpengetahuan baik dengan pekerjaan Ibu rumah tangga memberikan sumbangan terbanyak dalam mengenali masa menopause. Ibu rumah tangga memiliki pola aktivitas keseharian yang berfokus pada pekerjaan rumah seperti membereskan rumah, mengasuh anak, memasak, mencuci dan lainnya sehingga lebih merasakan masa menopause pada kesehatan fisik lanjut sesuai dengan pengetahuan Ibu. Berbeda dengan Ibu yang memiliki pekerjaan sebagai PNS, petani, dan wiraswasta yang lebih banyak dan berat sehingga tidak terlalu terfokus pada masa menopause yang dialami. Maka peneliti menyimpulkan, pengetahuan baik ibu menopause berdasarkan pekerjaan berada pada Ibu rumah tangga.

\section{Gambaran Pengetahuan Ibu Menopause Tentang Kesehatan Fisik Selama}

Menopause Berdasarkan Sumber informasi

Berdasarkan hasil penelitian tabel 5, diperoleh bahwa pengetahuan ibu menopause tentang kesehatan fisik selama menopause berpengetahuan baik berdasarkan sumber Informasi dari tenaga kesehatan sebanyak (30\%). Sedangkan Ibu yang berpengetahuan cukup dari sumber informasi Keluarga, dan tidak di temukan media cetak dan pengetahuan kurang berdasarkan sumber informasi yang didapat oleh ibu.

Sumber informasi adalah media yang berperan penting bagi seseorang dalam menentukan sikap dan keputusan untuk bertindak. Sumber informasi itu dapat diperoleh dengan bebas mulai dari keluarga, lingkungan tempat tinggal teman sebaya, organisasi, buku-buku, film, video, bahkan dengan mudah membuka situs-situs lewat internet (Taufik \& Ermawati, 2017).

Sejalan dengan penelitian (Batan et al., 2013),didapatkan pengetahuan baik terbanyak berdasarkan sumber informasi menopause dari petugas kesehatan yaitu $84,6 \%$, 
sedangkan pengetahuan tidak baik terbanyak yaitu yang tidak mendapat sumber informasi menopause dari siapapun atau tidak tahu sebesar $100 \%$. Hal ini sesuai dengan penelitian Erna Rahmayanti pada tahun 2005 yang menyimpulkan bahwa tingkat pengetahuan dan sikap ibu tentang klimakterium akan mempengaruhi tindakan preventif wanita menjelang menopause. Penyuluhan seputar klimakterium dan diskusi-diskusi tentang menopause yang dipandu oleh petugas kesehatan akan sangat baik jika dilakukan. Responden yang memiliki pengetahuan baik tentang menopause sebanyak 30 orang $(60 \%)$, sedangkan responden yang memiliki pengetahuan tidak baik tentang menopause sebanyak 20 orang $(40 \%)$.

Berdasarkan asumsi peneliti, bahwa Ibu menopause berpengetahuan baik dengan sumber informasi dari tenaga kesehatan yang mempengaruhi ibu selama menopause terutama dalam kesehatan fisik. Ibu berpengetahuan baik mengatakan banyak mendapatkan informasi dari tenaga kesehatan bidan,secara detail dalam mengenali masa menopause, sehingga hal tersebut menjadi pengetahuan yang didapat untuk lebih memahami dan mengantisipasi pada diri ibu menopause tentang kesehatan fisik. Sedangkan Ibu pengetahaun cukup tidak membuktikan bahwa ibu minim dan tidak mengetahui sama sekali mengenai pengertian dan masa menopause. Dengan pemahaman yang telah diberikan, diharapkan seluruh responden tetap mempertahankan pengetahuan yang diperoleh serta memanfaatkan media yang lebih banyak lagi dalam mendapatkan informasi tentang kesehatahan fisik selama menopause.

\section{Kesimpulan}

Dari hasil penelitian yang dilakukan, disimpulkan bahwapengetahuanIbu menopause tentangkesehatanfisikselama menopause di KlinikPratamaHenyKasihkota Medan Tahun 2021, Sebagian besaribu menopause memiliki pengetahuan yang baik. Ibu menopause diharapkan dapat memahami tanda dan gejala di masa menopause dengan mengenali dan melakukan berbagai pola hidup sehat, sepeti olahraga ringan, terapi rilekssasi, komsumsi makanan dan minuman sehat serta rutin memeriksakan kesehatan diri untuk tetap menjaga kesehatan fisik selama menopause. Diharapkan kepada tenaga kesehatan dan peneliti selanjutnya untuk lebih memberikan penyuluhan serta pemberian informasi kepada ibu premenopause dan ibu menopause dengan tanda dan gejala yang berdampak pada kesehatan fisik ibu selama menopause

\section{Referensi}

Arini, L. A. (2018). Kualitas Hidup Menopause yang Rutin Melakukan Latihan Fisik Orhiba: Studi Pengukuran Menggunakan Kuisioner WHOQOL-BREF. Seminar Nasional Riset Inovatif, 27-35.

Asifah, M., Daryanti, M. S., \& Wanita, P. (2021). Pengetahuan Wanita Dalam Menghadapi Menopause Di Pedukuhan Gowok. JKM Jurnal Kesehatan Masyarakat STIKES Cendekia Utama Kudus, 8, 180-191. https://www.jurnal.stikescendekiautamakudus.ac.id/index.php/JKM/article/view/68 2

Asriati, C. R., Wijaya, M., Nirmala, S. A., Gondodiputro, S., \& Rahmiati, L. (2019). Gambaran Pengetahuan Ibu tentang Persiapan Fisik dan Psikis Memasuki Masa $\begin{array}{llll}\text { Menopause. Jurnal Kesehatan } & \text { Vokasional, }\end{array}$ https://doi.org/10.22146/jkesvo.41638 
Badan Pusat Statistik. (2021). Hasil Sensus Penduduk 2020. Bps.Go.Id, 27, 1-52. https://papua.bps.go.id/pressrelease/2018/05/07/336/indeks-pembangunan-manusiaprovinsi-papua-tahun-2017.html

Batan, I. S., Mewengkang, M., \& Tendean, H. M. M. (2013). Pengetahuan Ibu Tentang Menopause Di Poliklinik Blu Rsu Prof. Dr. R. D. Kandou Manado. Jurnal EBiomedik, 1(1), 364-370. https://doi.org/10.35790/ebm.1.1.2013.4564

Cipto, C., Siswoko, S., \& Saptaningrum, E. (2020). Tingkat Pengetahuan Dan Sikap Ibu Menghadapi Masa Menopause. Jurnal Studi Keperawatan, 1(1), 6-9. https://doi.org/10.31983/j-sikep.v1i1.5644

Hekhmawati, S. (2016). Gambaran Perubahan Fisik dan Psikologis Pada Wanita Menopause di Posyandu Desa Pabelan. Universitas Muhammadiyah Surakarta, 13.

Indonesia, S. (2017). Statistika Indonesia 2017.

Indrawati, N. D., Kusumawati, E., \& Maria, R. (2019). Nutrition and contraception: The most influence factors in extending the age of menopause. IOP Conference Series: Earth and Environmental Science, 292(1). https://doi.org/10.1088/1755$1315 / 292 / 1 / 012014$

Kamal, N. N., \& Seedhom, A. E. (2017). Quality of life among postmenopausal women in rural Minia, Egypt. Eastern Mediterranean Health Journal, 23(8), 527-533. https://doi.org/10.26719/2017.23.8.527

Kesehatan, P. (2018). Data Dan Informasi.

Linda, L., \& Yetti R., E. (2019). Hubungan Perubahan Fisik Dengan Kesiapan Ibu Dalam Menghadapi Menopause Di Wilayah Kerja Puskesmas Maroangin Kota Palopo. MPPKI (Media Publikasi Promosi Kesehatan Indonesia): The Indonesian Journal of Health Promotion, 2(1), 33-40. https://doi.org/10.31934/mppki.v2i1.526

Manalu, H. L. L. (2020). Gambaran pengetahuan ibu menopause tentang perubahan fisik selama masa menopause. Excellent Midwifery Journal, 3(1), 79-87.

Matjino, S. H. (2019). Pengaruh Penyuluhan Tentang Menopause Terhadap Tingkat Kecemasan Ibu Dalam Menghadapi Menopause Di Kelurahan Toboleu Kecamatan Kota Ternate Utara. Jurnal Medikes (Media Informasi Kesehatan), 6(2), 203-216. https://doi.org/10.36743/medikes.v6i2.184

Miftachul ulum. (2016). B u k u uji validitas dan uji reliabilitas. Buku Uji Validitas Dan Uji Reliabilitas, 67.

Prabhakara, G. (2019). Kementerian kesehatan republik indonesia. In Short Textbook of Preventive and Social Medicine. https://doi.org/10.5005/jp/books/11257_5

Rakkuea, S., Nur, A. W., \& NS, E. T. N. (2016). Gambaran Pengetahuan Wanita Tentang Menopause Di Dukuh Sorobaon Kelurahan Jati Kecamatan Jaten Kabupaten Karangayar. http://eprints.ums.ac.id/id/eprint/46564

Saraniga, P. A. (2017). Pengetahuan Tentang Menopause Pada Wanita Usia 40-60 Tahun Di Kelurahan Anduonohu Kecamatan Poasia Kota Kendari. 1-78.

Shim, H., Shin, N., Stern, A., Aharon, S., Binyamin, T., Karmi, A., Rotem, D., Etgar, L., Porath, D., Pradhan, B., Kumar, G. S., Sain, S., Dalui, A., Ghorai, U. K., Pradhan, S. K., Acharya, S., Quan, L. N., Rand, B. P., Friend, R. H., ... Gmbh, Z. (2018). Advanced Optical Materials, 10(1), 1-9.

Taufik, A., \& Ermawati. (2017). Perancangan Sistem Informasi Pemesanan Pentas Seni Berbasis Web Pada Sanggar Seni Getar Pakuan Bogor. IJSE - Indonesian Journal on Software Engineering, $3(2), \quad 1-7$. http://ejournal.bsi.ac.id/ejurnal/index.php/ijse/article/view/2812/1836

Theresia Bong, M., Mudayatiningsih, S., Program Studi Ilmu Keperawatan Fakultas Ilmu Kesehatan Universitas Tribhuwana Tunggadewi Malang, M., \& Program Studi Ilmu Keperawatan Fakultas Ilmu Kesehatan, D. (2019). Hubungan Pengetahuan Ibu 
JINTAN: Jurnal Ilmu Keperawatan

ISSN 2774-468X (Media Online)

Vol 2, No 1, Bulan Januari 2022

Hal 59-70

Tentang Menopause dengan Tingkat Stress. Nursing News, 4(1), 112-122. https://publikasi.unitri.ac.id/index.php/fikes/article/download/1485/1052

Tsuraya, M. (2018). Gambaran Mekanisme Koping Wanita Dalam Menghadapi Perubahan Fisik Akibat Menopause. 164-173.

WHO. (1981). Research on the menopause. A report of the WHO Scientific Group. In World Health Organization Technical Report Series No. 670 (pp. 1-79). http://www.who.int/iris/handle/10665/41526 